\title{
Effect of Fluid Chemistry on the Consolidation and Hydraulic Conductivity of Sand-Clay Liners
}

\author{
Muawia Dafalla
}

check for

updates

Citation: Dafalla, M. Effect of Fluid Chemistry on the Consolidation and Hydraulic Conductivity of Sand-Clay Liners. Sustainability 2021, 13, 11213. https://doi.org/10.3390/su132011213

Academic Editor: Hossein Bonakdari

Received: 8 September 2021

Accepted: 5 October 2021

Published: 11 October 2021

Publisher's Note: MDPI stays neutral with regard to jurisdictional claims in published maps and institutional affiliations.

Copyright: (C) 2021 by the author. Licensee MDPI, Basel, Switzerland. This article is an open access article distributed under the terms and conditions of the Creative Commons Attribution (CC BY) license (https:// creativecommons.org/licenses/by/ $4.0 /)$.
Bugshan Research Chair in Expansive Soils, Civil Engineering, King Saud University, Riyadh 11421, Saudi Arabia; mdafalla@ksu.edu.sa

\begin{abstract}
The clay swelling potential of sand-clay liners exposed to saline water or specific chemicals can influence their hydraulic conductivity and other consolidation properties. The effect of saline water or chemicals on the sand-clay liners was thus studied and evaluated. The consolidation characteristics of the sand-clay liner can be different when tested under different fluid media. Bentonite and cement grouts are chemicals that have a significant effect on the sand-clay liners. Cement and bentonite can be used to seal off the openings within the liner to repair a defect or a malfunction. In this study, Al-Qatif clay was used to form a sand-clay liner when mixed with fine-grained sand (clay is $20 \%$ by dry weight). Soil samples extracted from this liner were exposed to inorganic chemical solutions. $\mathrm{NaCl}$ and $\mathrm{CaCl}_{2}$ solutions with concentration ranges of $0.1 \%, 0.5 \%$, and $1.5 \%$ were used. Acidic water with $\mathrm{pH}$ values of 4,5, and 6 was similarly used as fluid media. The effects of $\mathrm{NaCl}$, $\mathrm{CaCl}_{2}$, and water with different acidity on the consolidation characteristics and hydraulic conductivity were obtained and compared to those of the distilled water. The effects of grout materials containing bentonite $(1 \%, 2 \%$, and $3 \%$ by weight $)$ and cement $(2.5 \%, 5 \%$, and $7.5 \%$ by weight) were also investigated. The addition of bentonite grout to the liner surface was found to improve its hydraulic conductivity. The cement effect on the compressibility was found to be very significant. The findings of this study can serve as a guide for selecting parameters in the design and assessment of sand-clay liners in semi-arid regions and coastal zones.
\end{abstract}

Keywords: sand-clay; clay; liners; consolidation; hydraulic conductivity

\section{Introduction and Objectives}

The influence of salts and fluids of different ionic concentrations on the behavior of expansive clayey soils has attracted the attention of many researchers, whose studies have been mainly focused on the physicochemical changes and mechanisms associated with the introduction of such fluids. The effect of ions in pore water was first studied while investigating the compressibility of bentonite: the presence of salts was found to be strictly related to the double-layer interactions within clay particles [1]. Mitchell [2] stated that an increase in the pore fluid's ion concentration is associated with a reduction of the distance between double layers. Since clays can have different origins and variable mineralogical compositions, their physicochemical responses to water and fluids can also be different [3-5]. Sand-clay mixtures are frequently utilized in liners and in the waste containment industry, in which highly plastic and expansive clay is used. Processed clay, rich in montmorillonite or smectite minerals, is called bentonite. $\mathrm{Na}^{+}$Wyoming bentonite $\left(\mathrm{Na}^{+}\right.$-smectite clay) has received considerable attention since it can absorb large quantities of water and swell more than other types ( $\mathrm{Ca}^{++}$-smectite clay). Wigger and Van Loon [6] studied the influence of sodium chloride and calcium chloride on the clays and marl. They noticed an increase in anion porosity, with increasing molar concentration. The anion accessible porosity is shown as increasing from 3\% at low ionic strength $(0.01 \mathrm{M})$ up to $8.4 \%$ at high ionic strength $(5 \mathrm{M})$.

Highly plastic and unprocessed local clays are presently used as environmentally friendly alternatives to bentonite in liners and other sand-clay backfills $[7,8]$. Research 
work on the chemical effect of chlorides is covered in more detail in the field of expansive soil stabilization. Zumrawi et al. [9] studied the effects of three different chloride salts on the swelling properties of expansive soils. These are aluminum chloride $\left(\mathrm{Al} \mathrm{Cl}_{3}\right)$, ferric chloride $\left(\mathrm{Fe} \mathrm{Cl}_{2}\right)$, and ammonium chloride $\left(\mathrm{NH}_{4} \mathrm{Cl}\right)$. It was found that all investigated chloride compounds reduced the liquid limit and plasticity index. Significant reduction is reported in the free swell index, swell potential, and swell pressure when these typical chlorides are added.

Several researchers, for example [10,11], introduced models for the mechanical behavior of expansive clays and/or bentonites. A basal spacing increase from 12.5 to $20 \AA$ was estimated for dry commercial bentonite to wet conditions [12-14].

Studies of Di Maio et al. [15] reported that pore fluid composition controls the volume change behavior of clays: an increase of the pore solution concentration decreases the compressibility and increases the consolidation coefficients. Additionally, the mechanical properties of swelling clay are affected by variations in the pore fluid $\mathrm{pH}$ [16].

Clays having higher salinity show less compression and swelling, but higher permeability than those having lower salinity; moreover, their compression index, swelling index, coefficient of consolidation, and permeability are always greater in the case of site water than in that of deionized water [17]. The exposure of bentonite clay to an inorganic solution can lead to the degradation of the hydraulic conductivity. The hydraulic conductivity is defined as the ease at which a fluid can flow through a material. It is normally given as a rate (e.g., cm/sec). Reference [18] suggested that polymer treatment can improve clays to be non-reactive to many organic and inorganic chemicals. Recent research studies introduced some polymers to enhance the bentonite used in geoenvironmental applications to reduce its hydraulic conductivity and limit the diffusion of aggressive solutions. Reference [19] reported a lower diffusion coefficient for polymer-enhanced bentonite compared to sodium non-enhanced bentonite using dilute $(5 \mathrm{mmol} / \mathrm{L})$ to aggressive $(100 \mathrm{mmol} / \mathrm{L})$ calcium chloride $\left(\mathrm{CaCl}_{2}\right)$ solutions.

Zhang et al. [20] interestingly observed a close association between the mechanical behavior of clays and particle flocculation: increased bentonite content corresponded to a decrease of the permeability coefficient with pore water salinity. This trend has not been commonly reported by other researchers; nevertheless, it suggests that high bentonite content can suppress the action of salts.

The clay swell potential of sand-clay liners exposed to saline water or specific chemicals can decrease, affecting their hydraulic conductivity and other consolidation properties. The level of influence of saline water or chemicals on the sand-clay liners needs to be studied and evaluated. The consolidation characteristics of the fill can be influenced by the fluid media chemical composition within and around the sand-clay liners. Bentonite and cement grouts can be used to seal off openings within the liner to repair a possible malfunction. The findings of this study can be applied to the preservation of sand-clay liners as efficient barriers. Repair of the of clay-sand liners using chemical grouts is not practiced due to the unknown level of improvement in the hydraulic conductivity and strength characteristics provided. This study presents quantitative measures for using bentonite, cement, and other chemicals in grouts for the clay-sand liners repairs.

\section{Materials and Methods}

\subsection{General}

Highly plastic clay soils are abundant in many semi-arid regions and have been frequently proposed as an alternative to bentonite in sand-clay backfills since they are environmentally friendly and can potentially reduce the demand for processed clay imports. The main challenge in using these local soils for liner fill is ensuring that they have a suitable hydraulic conductivity: they should have a permeability of $10^{-7} \mathrm{~cm} / \mathrm{s}$ to represent a solid hydraulic barrier and ensure the containment of waste material [21,22]. Many research studies conducted in Saudi Arabia confirmed that Al-Qatif clay has a good potential as an additive for enhancing the performance of sand-clay liners. Here, commercial bentonite 
and Al-Qatif clay were considered while studying the swell and compressibility properties of the selected sand-clay liners.

\subsubsection{Al-Qatif Clay}

The Al-Qatif area is located along the Arabian Gulf coast, $400 \mathrm{~km}$ east of Riyadh city (Saudi Arabia). Studies conducted on the expansive Al-Qatif clay covered its geotechnical and engineering characteristics: due to its high smectite mineral content and resultant high plasticity, this clay is considered to be problematic.

Tables 1 and 2 present the geotechnical characteristics and the chemical composition of Al-Qatif clay, respectively.

Table 1. Physical properties of Al-Qatif clay (after Dafalla, 2017).

\begin{tabular}{cc}
\hline Property & Range \\
\hline Material passing sieve number 200 & $>90 \%$ \\
Liquid Limit (\%) & $130-150 \%$ \\
Plastic Limit (\%) & $60-70 \%$ \\
Plasticity Index & $70-80$ \\
Maximum Dry density (kN/m $\left.{ }^{3}\right)$ & $11.5-12$ \\
Optimum Moisture Content & $32-40 \%$. \\
Swell percent (ASTM D4546) & $16-18 \%$ \\
Swelling pressure (ASTM D4546) & $500-800 \mathrm{kN} / \mathrm{m}^{2}\left(\gamma=12 \mathrm{kN} / \mathrm{m}^{2}\right)$ \\
\hline
\end{tabular}

Table 2. Typical chemical composition of clays used in this study.

\begin{tabular}{|c|c|c|c|c|c|c|c|}
\hline \multicolumn{8}{|c|}{ Al-Qatif Clay } \\
\hline $\mathrm{K}^{+}(\%)$ & $\mathrm{K}_{2} \mathrm{O}(\%)$ & $\mathrm{Al}^{3+}(\%)$ & $\mathrm{Al}_{2} \mathrm{O}_{3}(\%)$ & $\mathrm{Si}(\%)$ & $\mathrm{SiO}_{2}(\%)$ & $\mathrm{Ca}^{2+}(\%)$ & $\mathrm{CaO}(\%)$ \\
\hline 1.8 & 2.2 & 3.3 & 6.3 & 8.1 & 17.3 & 0.7 & 0.9 \\
\hline \multicolumn{8}{|c|}{ HY OCMA Bentonite } \\
\hline $\mathrm{FeO}_{3}(\%)$ & $\mathrm{K}_{2} \mathrm{O}(\%)$ & $\mathrm{Na}_{2} \mathrm{O}(\%)$ & $\mathrm{Al}_{2} \mathrm{O}_{3}(\%)$ & $\mathrm{MgO}(\%)$ & $\mathrm{SiO}_{2}(\%)$ & $\mathrm{TiO}_{2}(\%)$ & $\mathrm{CaO}(\%)$ \\
\hline 2.9 & 0.1 & 1.9 & 17.0 & 4.6 & 55.2 & $<0.1$ & 0.9 \\
\hline
\end{tabular}

\subsubsection{Sand}

The sand is poorly graded and classified as SP, following ASTM D2487-11 [23] specifications. It is very popular in the area, being used for different construction purposes, and has a grading range of $0.1-0.6 \mathrm{~mm}$ (Figure 1 ).

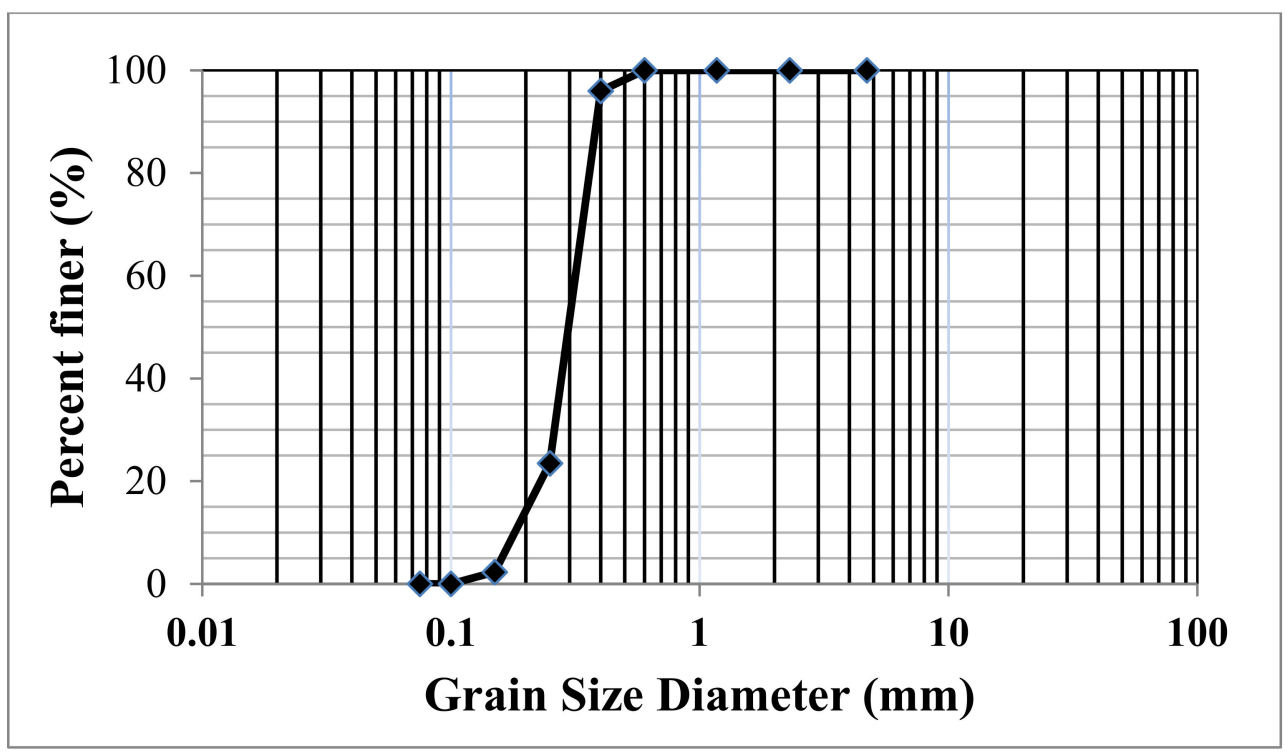

Figure 1. Grain size distribution of the sand used. 


\subsection{3. $\mathrm{NaCl}$}

A high-quality $\mathrm{NaCl}$ compound, represented by a $99 \%$ pure inorganic white powder, was used in this study.

\subsection{4. $\mathrm{CaCl}_{2}$}

A high-quality $\mathrm{CaCl}_{2}$ compound, represented by a $98 \%$ pure inorganic white powder, was used in this study.

\subsubsection{Cement Material}

In this study, cement grout was introduced in the form of ordinary Portland cement (OPC). The specifications of this cement corresponded to those of Type 1, in accordance with ASTM C159 [24]. $\mathrm{CaO}, \mathrm{SiO}_{2}, \mathrm{Al}_{2} \mathrm{O}_{3}$, and ferric oxides were constituents of the OPC.

\subsubsection{Bentonite}

In this study, grout with different bentonite concentrations was introduced in the form of commercial HY OCMA bentonite. The index properties of the bentonite used indicated a liquid limit of 480 , a plastic limit of 50 , and a plasticity index of 430 . The specific gravity was measured at 2.76. The chemical composition of the HY OCMA bentonite is given in Table 2.

\subsection{Compaction Tests}

Al-Qatif clay samples collected in the field were air-dried, pulverized, and sieved using \#40 sieve (pore size $=425 \mu \mathrm{m}$ ). To remove moisture, the clay was oven-dried. The clay was then mixed thoroughly with sand, achieving a clay content of $20 \%$ by dry weight. The water content required for the compaction tests was re-added gradually. The compaction tests used to assess the optimum water contents and maximum dry unit weights of the sand/Al-Qatif expansive clay mixtures were conducted through the standard Proctor compaction method, following ASTM D698 [25]. The mixtures were prepared by adding $3-22 \%$ of distilled water. The mixture was compacted into a mold (internal diameter = $101.6 \mathrm{~mm}$ (4 in); height $=113.9 \mathrm{~mm}(4.5 \mathrm{in}))$ using a $2.5 \mathrm{~kg}(5.5 \mathrm{lb})$ hammer and in three layers. The compaction curves obtained for the selected sand-clay mixtures were used to establish the dry density and the water content relationship.

\subsection{Compressibility Tests}

One-dimensional consolidation tests were conducted following conventional oedometer methods: each soil sample was contained in a ring (diameter $=50 \mathrm{~mm}$ ) within a consolidation cell. Two porous disks, attached with filter papers at the top and bottom of the sample, allowed the inward and outward flow of water. A loading frame was used to apply vertical loads through specially designed lever arms; also, a deformation digital sensor connected to a data logger (accuracy $=0.01 \mathrm{~mm}$ ) was used to monitor the changes in sample height.

The samples for the oedometer tests were prepared to achieve an optimum moisture content of $16 \%$ and a maximum dry density of $18.64 \mathrm{kN} / \mathrm{m}^{3}$. The calculated amount of the mixture was placed in three lifts in the ring by hand tamping. The initial heights and weights of the samples were measured before conducting the test following ASTM D2435 [26]. Different inundation fluids were tested including distilled water and fluids with variable concentrations of $\mathrm{NaCl}(0.1 \%, 0.5 \%$, and $1.5 \%)$ and $\mathrm{CaCl}_{2}(0.1 \%, 0.5 \%$, and $1.5 \%)$; moreover, waters with different $\mathrm{pH}$ were also used. In order to investigate the effects of bentonite and cement grout solutions, different cement and bentonite concentrations were adopted $(1 \%, 2 \%, 3 \%$, and $4 \%$ for bentonite; $2.5 \%, 5 \%, 7.5 \%$, and $10 \%$ for cement). The samples were tested using method A (described in ASTM D4546-96 (2012) [27] (method A)) and consolidation loads were applied above the swelling level. Loading pressures of $25,50,100,200,400$, and $800 \mathrm{kPa}$ were applied and then off-loaded at 400, 200, and $100 \mathrm{kPa}$. 
Each pressure was maintained for $24 \mathrm{~h}$ at free drainage and recharged from the top and bottom.

\subsection{Hydraulic Conductivity}

The hydraulic conductivity of the samples was determined using an indirect method from the consolidation test. Direct hydraulic conductivity measurements can be conducted using both falling head permeability or constant head tests. Consolidation tests, however, are quicker and allow for estimations under different loading conditions. Based on Terzaghi's theory on one-dimensional consolidation, hydraulic conductivity can be expressed as shown in Equation (1):

$$
\mathrm{k}=c_{v} m_{v} \gamma_{w},
$$

where $c_{v}$ is the coefficient of consolidation (which can be obtained using Taylor's square root or Casagrande's semi-logarithmic methods), $m_{v}$ the coefficient of volume compressibility, and $\gamma_{w}$ the unit weight of water.

\section{Results}

\subsection{General Test Results}

Figure 1 presents the grain size distribution of the sand used for the proposed fill: the data indicate that this sand is poorly graded and fine-grained. The choice of the sand type is a prime factor since it determines the amount of clay additive required to close up all voids. In this case, coarse-grained and rounded sand is the worse selection, because it would require the addition of more expansive clay. Laboratory porosity and the void ratio are commonly measured to characterize sand-clay mixtures.

Index properties (e.g., parameters like liquid and plastic limits) are used to roughly estimate the amount of clay swelling. Al-Qatif clay is highly plastic, with a liquid limit (up to 150) and a plasticity index (up to 80) comparable to those of Ca-bentonite. The compaction properties of this clay are presented in Figure 2. The maximum dry density for the sand-clay mixture with a $20 \%$ clay content was $18.64 \mathrm{kN} / \mathrm{m}^{3}$ for the optimum moisture content of $16 \%$. This clay content was selected since it results in a mixture with ideal properties (i.e., high dry density and optimum moisture). Mixtures of $15-20 \%$ clay can also be suitable. This study, however, only employed a sand-clay mixture of $20 \%$ clay.

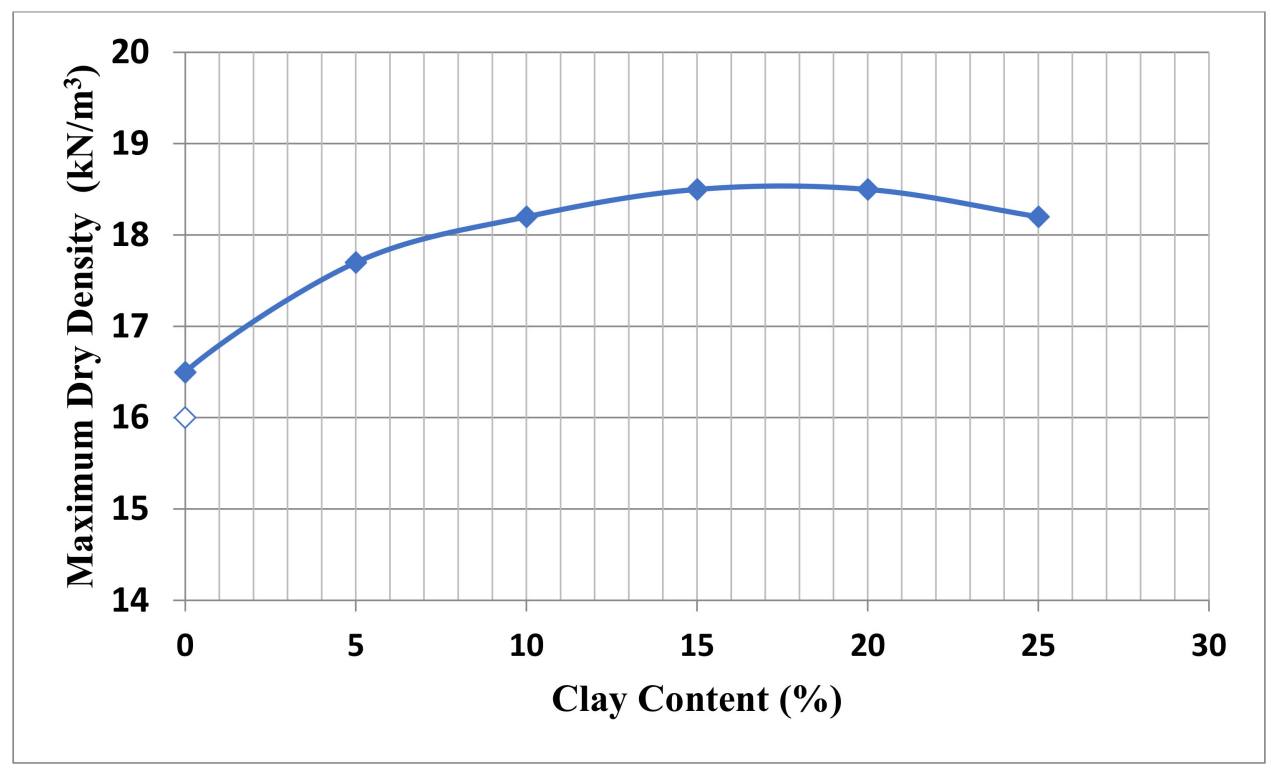

Figure 2. Relationship between the maximum dry density and clay content of sand-clay and sandbentonite mixtures. 


\subsection{Influence of $\mathrm{NaCl}$ Concentration}

Figure 3 shows the void ratio versus the log pressure of a sand-clay fill subjected to a fluid with $\mathrm{NaCl}$ at molar concentrations of $0.1,0.5$, and 1.5. A slight variation in the compressibility index was observed; however, the sample flooded with $1.5 \mathrm{NaCl}$ concentration was more compressible than the others, and its void ratio was reduced to less than 0.32 at a stress level of $1600 \mathrm{kN} / \mathrm{m}^{2}$. All samples were prepared with an initial void ratio of 0.420 to 0.440 , and the major changes took place at the first stress level (100 $\mathrm{kPa})$.

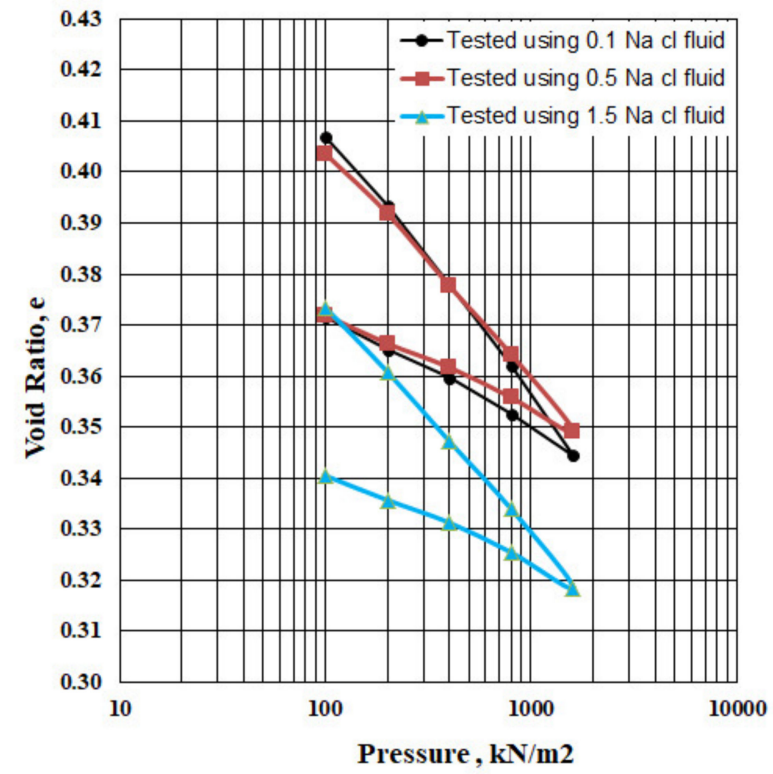

Figure 3. E-log p curve obtained from the consolidation tests using $\mathrm{NaCl}$ at different concentrations.

The application of the $\mathrm{NaCl}$ solutions caused the consolidation and collapse of the sand-clay mixture; as a result of the compression, its hydraulic conductivity was reduced (Table 3).

Table 3. Consolidation characteristics and hydraulic conductivity achieved at stress intervals of $100-200 \mathrm{kN} / \mathrm{m}^{2} \mathrm{while}$ using NaCl-salt fluids.

\begin{tabular}{|c|c|c|c|c|c|c|c|c|}
\hline $\begin{array}{c}\text { Chemical } \\
\text { Media }\end{array}$ & Concentration & $\begin{array}{c}e_{1} \\
\left(100 \mathrm{kN} / \mathrm{m}^{2}\right)\end{array}$ & $\begin{array}{c}e_{2} \\
\left(200 \mathrm{kN} / \mathrm{m}^{2}\right)\end{array}$ & $m_{v}\left(\mathrm{~m}^{2} / \mathrm{kN}\right)$ & $\begin{array}{c}C_{v}(200) \\
\left(\mathrm{m}^{2} / \text { Year }\right)\end{array}$ & $\begin{array}{c}\mathbf{k}(\mathrm{cm} / \mathrm{s} \times \\
\left.10^{-8}\right)\end{array}$ & $\begin{array}{c}C_{c}(100- \\
200) \mathrm{kN} / \mathrm{m}^{2}\end{array}$ & $\begin{array}{c}C_{\mathrm{r}}(100- \\
\left.200 \mathrm{kN} / \mathrm{m}^{2}\right)\end{array}$ \\
\hline \multicolumn{9}{|l|}{$\mathrm{NaCl}$} \\
\hline & $0.1 \mathrm{M}$ & 0.407 & 0.394 & $9.71 \times 10^{-5}$ & 1.3198 & 0.399 & 0.0452 & 0.021 \\
\hline & $0.5 \mathrm{M}$ & 0.404 & 0.392 & $8.37 \times 10^{-5}$ & 1.1252 & 0.293 & 0.0389 & 0.019 \\
\hline & $1.5 \mathrm{M}$ & 0.374 & 0.361 & $9.21 \times 10^{-5}$ & 1.6622 & 0.477 & 0.0419 & 0.016 \\
\hline \multicolumn{9}{|l|}{$\mathrm{CaCl}_{2}$} \\
\hline & $0.1 \mathrm{M}$ & 0.4067 & 0.391 & 0.000112235 & 2.445 & 0.853 & 0.0522 & 0.0236 \\
\hline & $0.5 \mathrm{M}$ & 0.3962 & 0.382 & 0.000102224 & 1.670 & 0.531 & 0.0472 & 0.0209 \\
\hline & $1.5 \mathrm{M}$ & 0.3989 & 0.3869 & $8.61512 \times 10^{-5}$ & 2.986 & 0.800 & 0.0399 & 0.0183 \\
\hline \multicolumn{9}{|l|}{ Acidic Water } \\
\hline & $\begin{array}{l}\mathrm{pH}=4 \\
\mathrm{pH}=5\end{array}$ & $\begin{array}{l}0.4065 \\
0.4097\end{array}$ & $\begin{array}{l}0.3942 \\
0.3978\end{array}$ & $\begin{array}{l}8.78352 \times 10^{-5} \\
8.47729 \times 10^{-5}\end{array}$ & $\begin{array}{l}2.9968 \\
3.0114\end{array}$ & $\begin{array}{l}0.819 \\
0.794\end{array}$ & $\begin{array}{l}0.049 \\
0.039\end{array}$ & $\begin{array}{l}0.021 \\
0.020\end{array}$ \\
\hline & $\mathrm{pH}=6$ & 0.4047 & 0.3895 & 0.000108797 & 2.0640 & 0.699 & 0.051 & 0.022 \\
\hline DW (Distilled) & $\mathrm{pH}=7$ & 0.4193 & 0.4051 & 0.000100552 & 2.1989 & 0.688 & 0.047 & 0.022 \\
\hline \multicolumn{9}{|c|}{ Cement grout } \\
\hline & $2.5 \%$ by wt & 0.4297 & 0.4196 & $7.08946 \times 10^{-5}$ & 1.6397 & 0.362 & 0.034 & 0.012 \\
\hline & $5.0 \%$ by wt & 0.4289 & 0.4186 & $7.23442 \times 10^{-5}$ & 3.6469 & 0.821 & 0.034 & 0.014 \\
\hline & $7.5 \%$ by wt & 0.4303 & 0.4211 & $6.45297 \times 10^{-5}$ & 4.4287 & 0.889 & 0.031 & 0.008 \\
\hline \multicolumn{9}{|c|}{ Bentonite grout } \\
\hline & $2 \%$ by wt & 0.4263 & 0.4139 & $8.73178 \times 10^{-5}$ & 1.5329 & 0.416 & 0.041 & 0.020 \\
\hline & $3 \%$ by wt & 0.4365 & 0.4249 & $8.10792 \times 10^{-5}$ & 2.1958 & 0.554 & 0.038 & 0.015 \\
\hline & $4 \%$ by wt & 0.4192 & 0.4069 & $8.70458 \times 10^{-5}$ & 1.8745 & 0.506 & 0.041 & 0.014 \\
\hline
\end{tabular}




\subsection{Influence of $\mathrm{CaCl}_{2}$ Concentration}

Figure 4 shows the void ratio versus the log pressure of a sand-clay backfill subjected to a fluid with $\mathrm{CaCl}_{2}$ at molar concentrations of $0.1,0.5$, and 1.5. The clay sand backfill became less compressible as the $\mathrm{CaCl}_{2}$ concentration increased. The highest compressibility index (0.040) was observed in the case of $\mathrm{CaCl}_{2}$ at a molar concentration of $1.5 \%$; moreover, the void ratio was reduced to $0.33-0.34$ at a stress level of $1600 \mathrm{kN} / \mathrm{m}^{2}$. All samples were prepared with an initial void ratio of 0.44 .

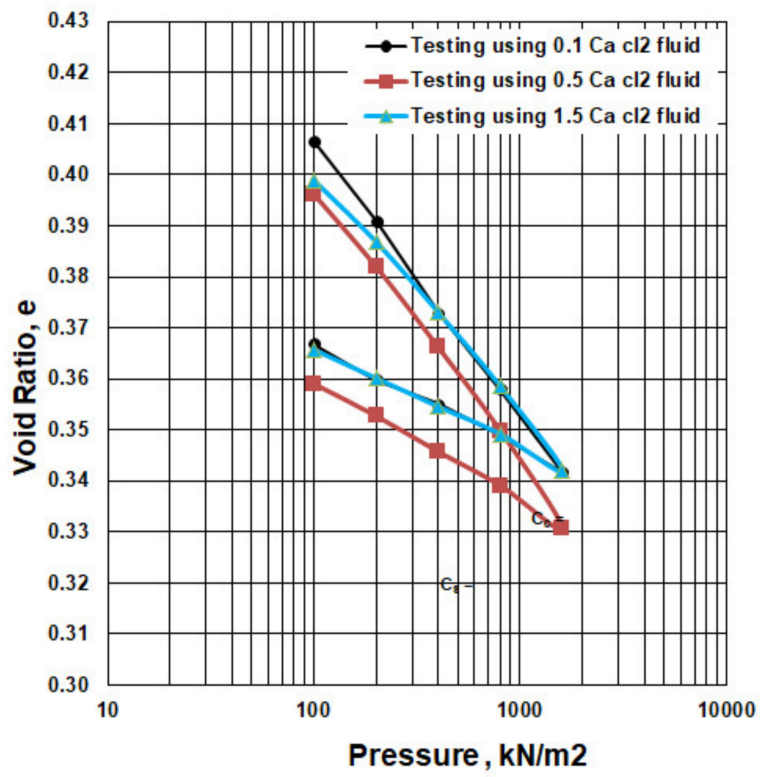

Figure 4. E-log $\mathrm{p}$ curve obtained from the consolidation tests using $\mathrm{CaCl}_{2}$ at different concentrations.

\subsection{Influence of $p H$}

Figure 5 shows the void ratio versus the log pressure of a sand-clay fill subjected to a fluid with variable $\mathrm{pH}$ values $(4,5$, and 6$)$. At a pH of 4 or 5 , the material's resistance to compression improved; moreover, the void ratio was at a minimum of 0.35 at $1600 \mathrm{kN} / \mathrm{m}^{2}$. At a $\mathrm{pH}$ of 6 , the backfill was subjected to higher compression, achieving a low void ratio (0.335).

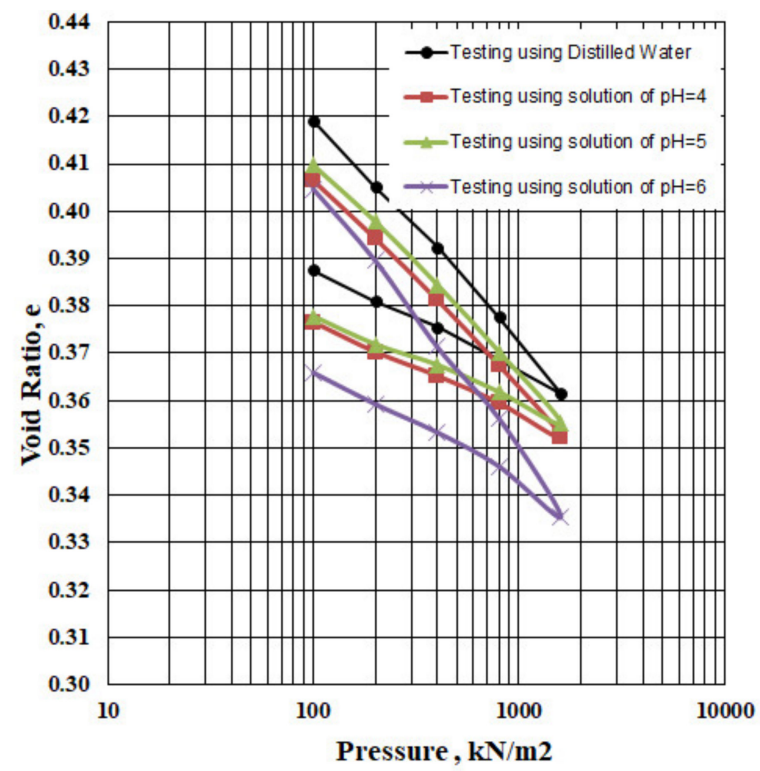

Figure 5. E-log $\mathrm{p}$ curve obtained from the consolidation tests using waters with different $\mathrm{pH}$. 


\subsection{Influence of Cement Grout Addition}

Figure 6 shows the void ratio versus the log pressure of a sand-clay fill subjected to a fluid with cement grout concentrations of $2.5 \%, 5 \%$, and $7.5 \%$ by weight. The sandclay material became less compressible after being treated with these three cement grout solutions. The compression and swell indices were almost identical for cement grout concentrations of $2.5 \%$ and $5 \%$, but slightly lower for concentrations of $7.5 \%$. Moreover, the void ratio was reduced from 0.43 to 0.38 at $1600 \mathrm{kPa}$, while the hydraulic conductivity was higher for cement grout concentrations of $5 \%$ and $7.5 \%$. Table 3 presents a summary of the tests conducted at variable cement grout concentrations.

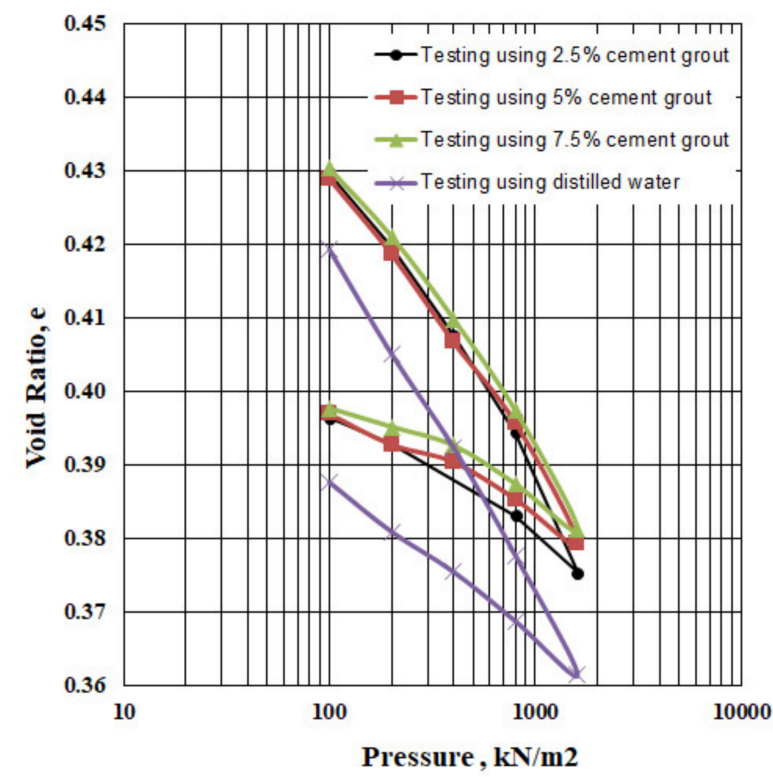

Figure 6. E-log p curve obtained from the consolidation tests using different concentrations of cement grout.

\subsection{Influence of Bentonite Grout Addition}

Figure 7 shows the void ratio versus the log pressure of a sand-clay fill subjected to bentonite grout fluids with concentrations of $2.5 \%, 5 \%$, and $7.5 \%$ by weight.

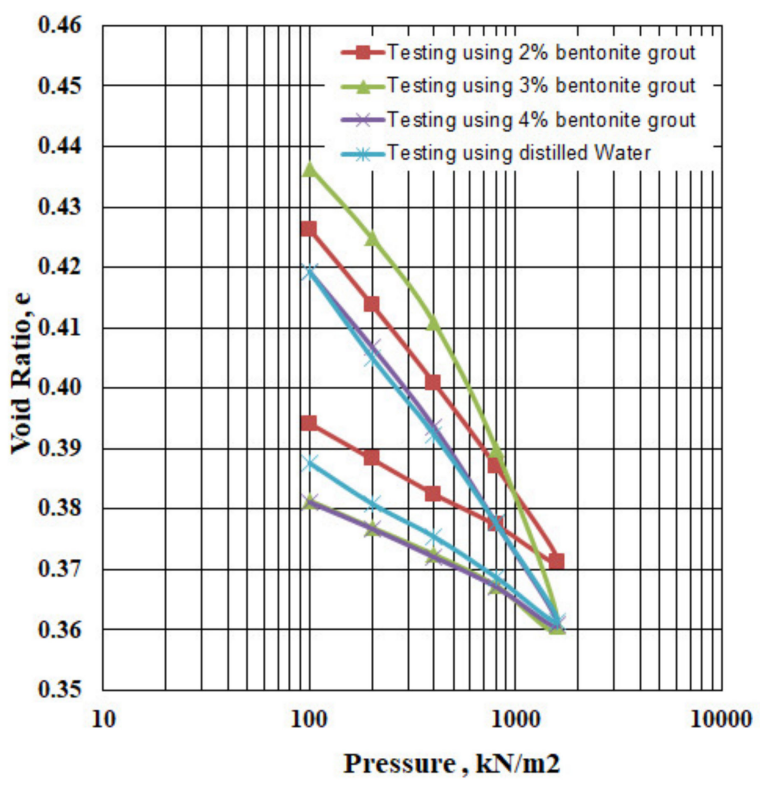

Figure 7. E-log p curve obtained from the consolidation tests using different concentrations of bentonite. 


\section{Discussion}

The mineralogy and chemistry of clays vary from area to area, depending on the geological settings and the parent rock from which they are derived. Therefore, the response of clays to chemical exposure also varies, although they follow a unique general trend. Extensive research has been carried out on the impact of ion concentration in water and other fluids on the behavior of expansive soils [28,29]; the results, in general, highlighted the important role of cation exchange capacity and of the double-layer theory.

This study simulated typical environmental changes occurring when a sand-clay fill is subjected to external fluids with an aggressive chemistry: it differs from previous studies, which investigated clays based solely on deionized inter-particle water. This work aimed to determine the impact of such fluids on the liner fill hydraulic conductivity and compressibility. Both of these characteristics determine the behavior of liners. Additionally, some specific solutions, which might help to repair the damages caused by chemical aggression to the liners and cover layers of sand-clay backfills, were examined.

Chemical additives were used as stabilizers for soils showing heave. For example, $\mathrm{KCl}, \mathrm{NaCl}, \mathrm{MgCl}_{2}, \mathrm{CaCl}_{2}$, and $\mathrm{AlCl}_{3}$ were all identified as good stabilizing agents [30]. For liners in which chemical additives are not employed, a reduction of the swell potential would typically translate in an easier infiltration of toxic materials into groundwater and a higher probability of damages in subsurface formations.

The application of the $\mathrm{NaCl}$ solutions caused the consolidation and collapse of the sand-clay mixture; as a result of the compression, its hydraulic conductivity was reduced. This result is in agreement with the findings of Belabaci [31] stating that the addition of chlorides increases the mechanical strength and the bearing capacity of clays. Reddy et al. [32] see $\mathrm{NaCl}$ as a "good stabilizer", since it helps in suppressing the expansion of plastic clay when applying a minimum effort; moreover, it can increase the hydraulic conductivity of liners, although not for all types of clay.

The application of $\mathrm{CaCl}_{2}$ at a molar concentration of 1.5, rather than 0.1 and 0.5 , resulted in a different compression index under the first two stress levels (200 and $400 \mathrm{kPa}$ ). The application of the $\mathrm{CaCl}_{2}$ solutions caused the sand-clay mixture to consolidate and halted its swelling. As a result of the compression, its hydraulic conductivity increased (for molar concentrations of 0.1 and $1.5 \mathrm{CaCl}_{2}$ ) to $0.800 \times 10^{-8} \mathrm{~cm} / \mathrm{s}$. In the case of the distilled water test, the resulting hydraulic conductivity was $0.688 \times 10^{-8} \mathrm{~cm} / \mathrm{s}$ (Table 3). The difference between these values shows how the performance of the sand-clay barrier was affected by the type of liquid used. The above hydraulic conductivity values are close to the limit of $1 \times 10^{-7} \mathrm{~cm} / \mathrm{s}$. According to Reference [33], it was found that calcium chloride gives better results than sodium chloride in terms of soil stabilization, but they recommended the use of sodium chloride for being cheaper than calcium chloride.

In reference to the $\mathrm{pH}$, the sample treated with distilled water had a higher initial void ratio, but the compression and swell indices were almost the same at $\mathrm{pH}$ values of 4 and 5. The steeper slope and higher stress levels observed at a pH of 6 might be due to chemical reactions at this level of $\mathrm{pH}$. A pH of 6 is less acidic and is likely linked to the physical changes; moreover, the hydraulic conductivity was found to increase with lowering the $\mathrm{pH}$. Table 3 presents a summary of the tests conducted at variable $\mathrm{pH}$ values. The tests conducted here do not represent severe exposure as classified by [34]. They defined extreme chemistry as strongly alkaline $(\mathrm{pH}>12)$, strongly acidic $(\mathrm{pH}<3)$, and hypersaline $(>1 \mathrm{M})$. Contact with strongly acidic leachates requires very special precautions for a good long-term performance.

The use of cement grout or adding cement to clay-sand mixture is not common in practice. The improvement in strength and cementation by adding cement is known and it can reduce the permeability. Works of Alkaya and Esener [35] confirmed that adding cement and bentonite to sand can help in providing an impervious mixture for use in earth-fill dams. Our results show that using a high concentration of cement may not serve the purpose of reducing permeability. This may be attributed to the formation of cement lumps and heterogeneous clay-sand mixtures. 
The addition of bentonite grout did not improve the compressibility of the sand-clay material. The compressibility did not change from one loading step to the other; however, the hydraulic conductivity improved significantly. This last parameter also increased with the bentonite grout concentration, but this was likely not due to the consistency of the paste. Grout may accumulate on the surface and also in the inner layers if they are accessible by the grout. Table 3 presents a summary of the tests conducted at variable bentonite grout concentrations. Reference [36] studied the groutability of granular soils using bentonite grout. Their work is more relevant to the permeation into the soil but the physicochemical interaction of the grout with the clay-sand mixture may be similar to the case of applying grout to a liner surface.

Dawar et al. [37] studied the influence of physical parameters on flow past a stretching sheet. The effect of microstructural slip parameter on the fluid flow and chemical reaction are investigated using analytical and numerical solutions for a model developed to assess the flow. This approach is very advanced and expected to predict the flow much better than the conventional approaches. More advanced work was introduced by recent works of Zafar et al. [38], where a non-linear model with diffusion was utilized to review the dynamics of the Lengyel-Epstein chemical reaction model to describe the oscillating chemical reactions. Shah et al. [39] studied nanofluid flow with activation energy and chemical reaction over nonlinearly stretching surfaces, where they highlighted the impact of velocity drag force, heat flux, and the concentration gradient.

Exposure to chemicals, which can occur naturally or as the result of remedy and stabilization actions, can have beneficial effects. Liners (especially top layers) are subjected to erosion and disintegration since they are subjected to variable environmental conditions. Acidic media can accelerate chemical reactions and cause the partial breaking of the cementation between particles. The addition of salts to expansive or swelling clays was found to reduce their swelling ability and reduce the clay potential to occupy all voids within a liner mixer. Exposure to such chemicals is inevitable when the prevailing fluids contain salts. In coastal areas, saline water from the sea or subsurface water can affect the clay liners, changing their hydraulic conductivity. If the hydraulic conductivity is not compromised, they can also improve the clay compressibility and solidification. The addition of $\mathrm{Ca}$ and cement is widely used worldwide as a stabilization technique: the resulting formation of pozzolanic compounds and clay aggregations increases the soil stiffness. The addition of bentonite grout, presented in this study, can be performed to enrich the liner with extra fines. This technique can be used to maintain and repair the liners from time to time; moreover, it can be applied between the layers to strengthen their barrier capacity and fluid retention.

\section{Conclusions}

The studied sand-clay mixture (containing Al-Qatif clay) was found to be very sensitive to chemical exposure: $\mathrm{NaCl}$ and $\mathrm{CaCl}_{2}$ affected its compressibility and hydraulic conductivity. The fluid $\mathrm{pH}$ regulated the occurrence of chemical reactions; moreover, the compressibility of the sand-clay mixture increased following the addition of cement grout and $\mathrm{CaCl}_{2}$. All the studied additives had some influence on the hydraulic conductivity of the mixture. In particular, the addition of bentonite grout ( $1-3 \%$ by weight) improved the hydraulic conductivity of Al-Qatif clay liners, suggesting its use in the repairing and maintenance of sand-clay liners. Repair of the of clay-sand liners using chemical grouts is not practiced due to the unknown level of improvement in the hydraulic conductivity and strength characteristics provided. This study presents quantitative measures for using bentonite, cement, and other chemicals in grouts for the clay-sand liners repairs.

The addition of bentonite grout, presented in this study, can be performed to enrich the liner with extra fines. This technique can be used to maintain and repair the liners from time to time; moreover, it can be applied between the layers to strengthen their barrier capacity and fluid retention. 
Funding: Deanship of Scientific Research at King Saud University. Grant reference: Vice Deanship of Scientific Research Chairs, BRCES.

Data Availability Statement: The data used to support the findings of this study are included in the introduced figures.

Acknowledgments: The author is grateful to the Deanship of Scientific Research, King Saud University, for funding through the Vice Deanship of Scientific Research Chairs.

Conflicts of Interest: The author declares that he has no conflict of interest.

\section{References}

1. Bolt, G.H. Physico-chemical analysis of the compressibility of pure clays. Géotechnique 1956, 6, 86-93. [CrossRef]

2. Mitchell, J.K. Fundamentals of Soil Behavior; Wiley: New York, NY, USA, 1976.

3. Zein, A.K.M. Comparison of measured and predicted swelling behavior of a compacted black cotton soil. In Proceedings of the Sixth International Conference on Expansive Soils, New Delhi, India, 1-4 December 1987; pp. 121-126.

4. Chen, F.H. Foundations on Expansive Soils; Elsevier: Amsterdam, The Netherlands, 1988.

5. Dafalla, M.A.; Al-Sharmrani, M.A. Performance-based solutions for foundations on expansive soils-Al Ghatt Region, Saudi Arabia. In Proceedings of the GEO-CHIANGMAI 2008: An International Conference on Geotechnical Engineering, Chiangmai, Thailand, 10-12 December 2008.

6. Wigger, C.; Van Loon, L.R. Effect of the pore water composition on the diffusive anion transport in argillaceous, low permeability sedimentary rocks. J. Contam. Hydrol. 2018, 213, 40-48. [CrossRef] [PubMed]

7. Langdon, N.J.; Al Hussaini, M.J.; Walden, P.J.; Sangha, C.M. An assessment of permeability of clay liners: Two case histories. In Engineering Geology Special Publications; Geological Society: London, UK, 2004; Volume 3.

8. Obrike, S.E.; Osadebe, C.C.; Omoniyi, S.S. Geotechnical analysis of two Nigerian soils for use as clay liners. Bull. Eng. Geol. Environ. 2009, 68, 417-419. [CrossRef]

9. Zumrawi, M.M.; Mahjoub, A.M.; Alnour, I.N. Effect of some chloride salts on swelling properties of expansive soil. Univ. Khartoum Eng. J. 2016, 6, 35-41.

10. Alonso, E.E.; Vaunat, J.; Gens, A. Modelling the mechanical behaviour of expansive clays. Eng. Geol. 1999, 54, 173-183. [CrossRef]

11. Mollins, L.H. The Design of Bentonite-Sand Mixtures. Ph.D. Thesis, University of Leeds, Leeds, UK, 1996.

12. Mollins, L.H.; Stewart, D.I.; Cousens, T.W. Predicting the properties of bentonite-sand mixtures. Clay Miner. 1996, 31, 243-252. [CrossRef]

13. Studds, P.G. The Effect of Ionic Solutions on the Properties of Soil. Ph.D. Thesis, University of Leeds, Leeds, UK, 1997.

14. Studds, P.G.; Stewart, D.I.; Cousens, T.W. The effects of salt solutions on the properties of bentonite-sand mixtures. Clay Miner. 1998, 33, 651-660. [CrossRef]

15. Di Maio, C.; Santoli, L.; Schiavone, P. Volume Change Behaviour of Clays: The Influence of Mineral Composition, Pore Fluid Composition and Stress State. Mech. Mater. 2004, 36, 435-451. [CrossRef]

16. Gajo, A.; Maines, M. Mechanical Effects of Aqueous Solutions of Inorganic Acids and Bases on a Natural Active Clay. Géotechnique 2007, 57, 687-699. [CrossRef]

17. Deng, Y.F.; Yue, X.B.; Cui, Y.J.; Shao, G.H.; Liu, S.Y.; Zhang, D.W. Effect of Pore Water Chemistry on the Hydro-Mechanical Behaviour of Lianyungang Soft Marine Clay. Appl. Clay Sci. 2014, 95, 167-175. [CrossRef]

18. Ashmawy, A.; Darwish, E.; Sotelo, N.; Muhammad, N. Hydraulic performance of untreated and polymer-treated bentonite in inorganic landfill leachates. Clays Clay Miner. 2002, 50, 546-552. [CrossRef]

19. Tong, S.; Sample-Lord, K.M.; Bohnhoff, G.L. Diffusion through sodium and polymer enhanced bentonites exposed to dilute and aggressive solutions. Can. Geotech. J. 2021. [CrossRef]

20. Zhang, F.; Ye, W.; Chen, Y.; Chen, B.; Cui, Y.J. Influences of Salt Solution Concentration and Vertical Stress During Saturation on the Volume Change Behavior of Compacted GMZ01 Bentonite. Eng. Geol. 2016, 207, 48-55. [CrossRef]

21. Daniel, D.E. Geotechnical Practice for Waste Disposal; Springer: Berlin/Heidelberg, Germany, 1993.

22. Rowe, R.K.; Quigley, R.M.; Booker, J.R. Clayey Barrier Systems for Waste Disposal Facilities; E \& FN Spon: London, UK, 1995; 404p.

23. Azam, S.; Abduljauwad, S.N.; Al-Shayea, N.A.; Al-Amoudi, O.S.B. Expansive Characteristics of gypsiferous/Hydritic Formations. Eng. Geol. 1998, 51, 89-107. [CrossRef]

24. Azam, S. Influence of Mineralogy on Swelling and Consolidation of Soils in Eastern Saudi Arabia. Can. Geotech. J. 2003, 40, 964-975. [CrossRef]

25. Dafalla, M.A. The compressibility and swell of mixtures for sand-clay liners. Adv. Mater. Sci. Eng. 2017, 2017, 3181794. [CrossRef]

26. ASTM D2435/D2435M-11. Standard Test Methods for One-Dimensional Consolidation Properties of Soils Using Incremental Loading; ASTM International: West Conshohocken, PA, USA, 2011.

27. ASTM D4546-96. Standard Test Methods for One-Dimensional Swell or Settlement Potential of Cohesive Soils; ASTM International: West Conshohocken, PA, USA, 1996.

28. Zhang, T.; Wang, S. Explanation of the Influence of Sodium Chloride Solution on Volume Deformation and Permeability of Normally Consolidated Clays. Materials 2019, 12, 1671. [CrossRef] [PubMed] 
29. Gueddouda, M.K.; Goual, I.; Lamara, M.; Smaida, A.; Mekarta, B. Chemical stabilization of expansive clays from Algeria. Glob. J. Res. Eng. 2011, 11, 1-8.

30. He, Y.; Chen, Y.; Ye, W.; Chen, B.; Cui, Y. Influence of Salt Concentration on Volume Shrinkage and Water Retention Characteristics of Compacted GMZ Bentonite. Environ. Earth. Sci. 2016, 75, 535. [CrossRef]

31. Belabbaci, Z.; Mamoune, S.M.A.; Bekkouche, A. Laboratory study of the influence of mineral salts on swelling ( $\mathrm{KCl}, \mathrm{MgCl} 2)$. Earth Sci. Res. 2013, 2, 135-142. [CrossRef]

32. Reddy, N.G.; Tahasildar, J.; Rao, B.H. Evaluating the Influence of Additives on Swelling Characteristics of Expansive Soils. Int. J. Geosynth. Ground Eng. 2015, 1, 40891. [CrossRef]

33. Kolaventi, S.S.; Venigalla, S.G.; Rakesh, D. Stabilization of Black Cotton Soil using Salts and Their Comparative Analysis. Int. J. Eng. Dev. Res. 2016, 4, 797-800.

34. Bouazza, A.; Gates, W.P. Overview of performance compatibility issues of GCLs with respect to leachates of extreme chemistry. Geosynth. Int. 2014, 21, 151-167. [CrossRef]

35. Alkaya, D.; Esener, A.B. Usability of sand-bentonite-cement mixture in the construction of unpermeable layer. Scientific Res. Essays 2011, 6, 4492-4503.

36. Yoon, J.; El Mohtar, C.S. Groutability of granular soils using sodium pyrophosphate modified bentonite suspensions. Tunn. Undergr. Space Technol. 2013, 37, 135-145. [CrossRef]

37. Dawar, A.; Shah, Z.; Tassaddiq, A.; Islam, S.; Kumam, P. Joule heating in magnetohydrodynamic micropolar boundary layer flow past a stretching sheet with chemical reaction and microstructural slip. Case Stud. Therm. Eng. 2021, 25, 100870. [CrossRef]

38. Zafar, Z.U.A.; Shah, Z.; Ali, N.; Kumam, P.; Alzahrani, E.O. Numerical study and stability of the Lengyel-Epstein chemical model with diffusion. Adv. Differ. Equ. 2020, 2020, 427. [CrossRef]

39. Shah, Z.; Kumam, P.; Deebani, W. Radiative MHD Casson Nanofluid Flow with Activation energy and chemical reaction over past nonlinearly stretching surface through Entropy generation. Sci. Rep. 2020, 10, 4402. [CrossRef] [PubMed] 